\title{
APLIKASI KONSEP NEGARA HUKUM DAN DEMOKRASI DALAM PEMBENTUKAN UNDANG-UNDANG DI INDONESIA*
}

\author{
Fauzi Iswari \\ Fakultas Hukum, Universitas Muhammadiyah Sumatera Barat, \\ Jl. Dr. M. Hatta RT.001 Rw.001 Kel. Pasar Ambacang Kec. Kuranji Kota Padang \\ e-mail: iswari.fauzi@gmail.com
}

\begin{abstract}
The involvement of the people in determining public policies, such as in the formation of laws, is a reflection of the state that synergizes law and democracy. This research aims to describe the application of the concept of a rule of law and democracy in the formation of laws in Indonesia. This type of research is normative legal research in which data is obtained from library materials or secondary data. The data analysis techniques (legal materials) used are qualitative analysis. From the results of the research conducted, it can be understood that the application of the principles of rule of law and democracy in the formation of laws in Indonesia, is ideally reflected in the application of the principles of legality, the principle of legal certainty, and the protection of human rights in a law. Meanwhile, the principle of democracy in the formation of laws can be seen from the existence of public involvement or participation in the formation of a law. However, what is happening in Indonesia today is that the formation of laws has led to indifference to the principles of a rule of law and democracy. This has resulted in protests and rejection of laws that have been passed as well as against bills being discussed in the legislative.
\end{abstract}

Keywords: Rule Of Law; Democracy; Constitution.

\begin{abstract}
Abstrak
Keterlibatan rakyat dalam penentuan kebijakan publik, seperti dalam pembentukan undangundang merupakan pencerminan suatu negara yang mensinerjikan antara hukum dan demokrasi. Penelitian ini bertujuan untuk menguraikan terkait aplikasi konsep negara hukum dan demokrasi dalam pembentukan undang-undang di Indonesia. Jenis penelitian yang digunakan adalah penelitian hukum normatif (normative legal research) yang perolehan datanya dari bahan-bahan pustaka atau data sekunder. Adapun teknik analisis data (bahan hukum) yang dipergunakan adalah dengan menggunakan analisis secara kualitatif. Dari hasil penelitian yang dilakukan, dapat dipahami bahwa pengaplikasian prinsip-prinsip negara hukum dan demokrasi dalam pembentukan undang-undang di Indonesia, idealnya tercermin dalam penerapan asas legalitas, prinsip kepastian hukum, dan perlindungan terhadap hak asasi manusia dalam sebuah undang-undang. Sementara prinsip demokrasi dalam pembentukan undang-undang tampak dari adanya keterlibatan atau partispasi publik dalam pembentukan suatu undang-undang. Sementara itu yang terjadi di Indonesia saat ini, dalam pembentukan undang-undang sudah mengarah pada pengabaian terhadap prinsip negara hukum dan demokrasi. Hal ini berdampak pada protes dan penolakan terhadap undang-undang yang sudah disahkan dan juga terhadap rancangan undang-undang yang sedang dibahas di lembaga legislatif.
\end{abstract}

Kata Kunci: Negara Hukum; Demokrasi; Undang-Undang.

\footnotetext{
* Naskah diterima: 19 Agustus 2020, direvisi: 23 September 2020, disetujui untuk terbit: 28 September 2020 Doi: 10.3376/jch.v6i1.285
} 


\section{PENDAHULUAN}

Undang-Undang Dasar Negara Republik Indonesia tahun 1945 (selanjutnya dibaca UUD NRI 1945), yang merupakan konstitusi tertulis di Indonesia dan juga merupakan refleksi dari cita-cita hukum bangsa Indonesia, secara eksplisit telah menggariskan beberapa prinsip dasar, di antaranya prinsip demokrasi dan prinsip Negara hukum. Kedua prinsip tersebut, termaktup dalam Pasal 1 ayat (2) dan (3) UUD NRI 1945.

Pada pasal 1 ayat (2) UUD NRI 1945 dijelaskan bahwa: "Kedaulatan berada di tangan rakyat dan dilaksanakan menurut Undang-Undang Dasar". Dengan demikian, maka dapat dikatakan, dalam UUD NRI 1945 tersebut secara tegas mendasar pada pemerintahan demokrasi karena pemerintahan tersebut dalam pelaksanaannya bersandar pada kedaulatan rakyat.(Cora Elly Noviati, 2013) Adapun prinsip negara hokum tertuang dalam Pasal 1 Ayat (3) UUD NRI 1945 yang menyatakan bahwa "Negara Indonesia adalah negara hukum".

Lebih lanjut terkait negara hukum, jauh sebelum termuat dalam UUD NRI 1945 secara historis negara hukum (rechtsstaat) adalah negara yang diidealkan oleh para pendiri bangsa (founding fathers). Hal ini sebagaimana tertuangkan dalam penjelasan umum UUD 1945 sebelum perubahan tentang sistem pemerintahan negara yang menyatakan bahwa: "Negara Indonesia berdasar atas hukum (rechtsstaat), tidak berdasarkan kekuasaan belaka (machtsstaat)".

Berkenaan dengan Negara hukum, di Indonesia apa yang tersirat dalam konstitusi tersebut baru hanya sebatas cita-cita. Hal ini sebagaimana dikemukakan oleh Jimly Asshiddqie (Jimly Asshiddiqie, 2010):

Negara Indonesia ialah "rechtsstaat", bukan "machtsstaat" (negara kekuasaan) atau pun korporatokrasi. Namun demikian, yang menjadi masalah pokok kita sekarang ini adalah bahwa perwujudan cita Negara Hukum itu sendiri masih sangat jauh dari kenyataan. Bahkan, dari waktu ke waktu, ciri-ciri negara hukum ideal itu sendiri dalam kenyataannya juga belum kunjung mendekati yang harapan.

Argumentasi Jimly di atas memberikan gambaran, bahwa pada tataran empiris, di Indonesia konsepsi tentang Negara hukum belum berjalan sesuai dengan yang semestinya, bahkan masih jauh dari yang diharapkan. $M$ endukung argumentasi Jimly tersebut, jika dilihat dari substansi pengaturannya, pemaknaan konsepsi negara hukum Indonesia saat ini kurang jelas seiring dengan tidak adanya penegasan akan negara hukum yang dianut Indonesia. (Siallagan, 2016)

Beranjak dari konsep Negara hukum, yang telah diuraikan di atas dan menyambung kembali tentang demokrasi yang telah terlebih dahulu disinggung sebelumnya. Menurut A Ramlan Surbakti, demokrasi terkait erat dengan rule of law (negara hukum). Di dalam UUD NRI 
Fauzi Iswari: Aplikasi Konsep Negara Hukum Dan Demokrasi Dalam Pembentukan...

1945, dibunyikan bahwa Indonesia bukan negara kekuasaan, tapi negara hukum. Rule of law itu artinya setiap penggunaan kekuasaan kewenangan itu berdasarkan atau mengikuti rambu-rambu yang ditetapkan oleh hukum, oleh undangundang. Bukan sebaliknya UU, rule by using law (Surbakti, 1999). Lebih lanjut berkenaan dengan hubungan hukum dan demokrasi Mahfud MD mengatakan:

Hubungan antara hukum dan demokrasi dapat diibaratkan dengan dua sisi mata uang, dalam arti bahwa kualitas hukum suatu Negara menentukan kualitas demokrasinya. Artinya, Negara-negara yang demokratis akan melahirkan pula hukum-hukum yang berwatak demokratis, sedangkan Negaranegara yang otoriter atau non demokratis akan lahir hukum-hukum yang non demokratis.(MD, 1999)

Dari pendapat Mahfud di atas dapat dipahami bahwa, Negara yang demokratis akan melahirkan hokum (peraturan perundang-undangan) yang demokratis pula, sedangkan Negara yang otoriter tentunya akan melahirkan peraturan perundang-undangan yang tidak demokratis. Oleh sebab itu, dalam arti yang lebih spesifik dapat diartikan bahwa undang-undang yang mengatur dan membatasi kekuasaan Negara atau pemerintah adalah undang-undang yang dibuat atas dasar-dasar kekuasaan atau kedaulatan rakyat.

Keterlibatan rakyat dalam penentuan kebijakan publik, seperti dalam pembentukan undang-undang merupakan pencerminan suatu negara yang mensinerjikan antara hukum dan demokrasi. Dalam tulisan ini, penulis akan menguraikan terkait aplikasi konsep negara hukum dan demokrasi dalam pembentukan undang-undang. Pembahasan ini menjadi menarik karena pada dekade terakhir ini banyak sekali undang-undang yang di-judicial review (diuji) ke Mahkamah Konstitusi. Bahkan, sebelum rancangan suatu undang-undang disahkan, sudah ada pihak-pihak yang berencana melakukan pengujiannya ke Mahkamah Konstitusi.

\section{METODE PENELITIAN}

Jenis penelitian yang penulis gunakan adalah penelitian hukum normatif (normative legal research). Menurut Soerjono Soekanto dan Sri Mamudji, penelitian hukum normatif atau penelitian kepustakaan yaitu penelitian hukum yang dilakukan dengan cara meneliti bahan pustaka atau data sekunder belaka.(Soerjono Soekanto dan Sri Mamudji, 2007)

Sebagai suatu penelitian hukum normatif, penelitian ini bermaksud meneliti bahan-bahan hukum yang ada di perpustakaan dalam rangka menjawab masalah yang akan diteliti. Hasil dari penelitian tersebut sifatnya teoritis bukan praktis. Oleh karena itu, dalam membahas pokok permasalahan dalam tulisan ini akan mengacu pada bahan hukum yang ada di perpustakaan atau data sekunder. 


\section{HASIL DAN PEMBAHASAN}

\section{A. Konsep Negara hukum dan demokrasi}

\section{Konsep Negara Hukum}

Secara defenisi, menurut Bintan R. Siragih sebagaimana dikutip oleh Nasrullah Muhammadong, bahwa negara hukum bisa dimaknai sebagai negara yang pada setiap tindakan pemerintah dan rakyatnya didasarkan atas hukum yang ditujukan untuk mencegah terjadinya tindakan pemerintah yang sewenangwenang dan tindakan rakyat yang dilakukan atas kehendaknya sendiri. (Muhammadong, 2017)

Jika ditelaah secara historis dan praktis, konsep negara hukum muncul dalam berbagai model seperti negara hukum menurut Al-Qur'an dan Sunnah atau Nomokrasi Islam, negara hukum menurut konsep Eropa Kontinental yang dinamakan rechtstaat, negara hukum menurut konsep Anglo-Saxon rule of law, konsep sosialist legality, dan konsep negara hukum Pancasila.(HR, 2011) Di sisi lain, Negara hukum dimulai dari konsepsi Negara hukum liberal (nachwachter staat/negara sebagai penjaga malam) ke negara hukum formal (formele rechtsstaat) kemudian menjadi negara hukum materiil (materiele rechtsstaat) hingga pada ide negara kemakmuran (welvaarsstaat) atau negara yang mengabdi kepada kepentingan umum (sosial service state atau sosiale verzorgingsstaat). (Wahjono, 1991)

Istilah "the rule of law" mulai populer dengan terbitnya sebuah buku dari Albert Venn Dicey tahun 1885 dengan judul "Introduction to the study of the law of de constitution". Berdasarkan latar belakang dan dari sistem hukum yang menopangnya terdapat perbedaan antara konsep "rechtsstaat" dengan konsep "the rule of law" meskipun dalam perkembangan dewasa ini tidak dipermasalahkan lagi perbedaan antara keduanya karena pada dasarnya kedua konsep itu mengarahkan dirinya pada satu sasaran yang utama yaitu pengakuan dan perlindungan terhadap hak-hak asasi manusia. Meskipun dengan sasaran yang sama tetapi keduanya tetap berjalan dengan sistem sendiri yaitu sistem hukum sendiri. Konsep "rechtsstaat" lahir dari suatu perjuangan menentang absolutisme sehingga sifatnya revolusioner, sebaliknya konsep "the rule of law" berkembang secara evolusioner. Hal ini nampak dari isi atau kriteria rechtstaat dan kriteria the rule of law. (Hadjon, 1987)

Adapun berkaitan dengan konsep negara hukum, menurut pendapat (Philipus M. Hadjon 1987) hanya ada 3 (tiga) konsep negara hukum, yaitu: rechtstaats, the rule of law, dan negara hukum pancasila. Kemudian (Azhary, 2010) mengemukakan ada lima (5) macam konsep negara hukum, sebagai species begrip yaitu:

a. Negara hukum menurut Qur'an dan Sunnah (Nomokrasi Islam) lebih tepat dan lebih memperlihatkan kaitan nomokrasi atau negara hukum itu dengan hukum Islam;

b. Negara hukum menurut Konsep Eropa Kontinental yang dinamakan 
Fauzi Iswari: Aplikasi Konsep Negara Hukum Dan Demokrasi Dalam Pembentukan...

rechtsstaat, model negara hukum ini diterapkan misalnya di Belanda, Jerman dan Perancis;

c. Konsep rule of law yang diterapkan di negara-negara Anglo-Saxon, antara lain Inggris dan Amerika Serikat;

d. Suatu konsep yang disebut sosialist legality yang diterapkan antara lain di Uni Soviet sebagai negara komunis; dan

e. Konsep Negara Hukum Pancasila.

Berkaitan dengan unsur-unsur Negara hukum, menurut Stahl, sebagaimana dikutip oleh (HR, 2011) dan (A. Mukthie Fadjar, 2005), bahwa unsur-unsur negara hukum (rechtsstaat) adalah sebagai berikut:

a. Perlindungan hak-hak asasi manusia;

b. Pemisahan atau pembagian kekuasaan untuk menjamin hak-hak itu;

c. Pemerintahan berdasarkan peraturan perundang-undangan; dan

d. Peradilan administrasi dalam perselisihan.

Pada wilayah anglo-saxon, muncul pula konsep negara hukum (rule of law) dari a.v. dicey, dengan unsur-unsur sebagai berikut:

a. Supremasi aturan-aturan hukum (supremacy of the law);

b. Tidak adanya kekuasaan sewenangwenang (absence of arbitrary power), dalam arti bahwa seseorang hanya boleh di hukum kalau melanggar hukum;

c. Kedudukan yang sama dalam menghadapi hukum (equality before of the law). Dalil ini berlaku baik untuk orang biasa maupun untuk pejabat; dan

d. Terjaminnya hak-hak manusia oleh undang-undang (di negara lain oleh undang-undang dasar) serta keputusan-keputusan pengadilan. (Saragih, 2000)

Merujuk pada berbagai pendapat dan pandangan terhadap unsur-unsur Negara hukum di atas. Adapun relevansinya dengan pembentukan undang-undang di Indonesia, setidaknya dapat dikerucutkan pada tiga hal, yaitu: (1) Asas Legalitas dan Prinsip kepastian hukum; (2) Aturan berdasarkan jenjang atau hierarki; dan (3) Perlindungan HAM. Dengan demikian, dapat dipahami bahwa dalam pembentukan undang-undang harus mengedepankan tiga hal tersebut. Setiap undang-undang dalam pembentukannya harus memenuhi asas legalitas atau dengan kata lain secara formal undangundang yang akan dibentuk tersebut harus ada dasar hukum pembentukannya. Setiap undang-undang juga harus menjadi rujukan terhadap persoalan yang sebelumnya belum atau tidak diatur dalam undang-undang lainnya.

Begitu juga dengan hierarki, bahwa setiap peraturan perundang-undangan yang lebih rendah tidak boleh bertentangan dengan yang lebih tinggi tingkatannya atau dengan kata lain undang-undang tidak boleh bertentangan dengan UUD. Selanjutnya, setiap undangundang yang dibentuk harus memberikan jaminan terhadap hak asasi manusia. 


\section{Konsep Demokrasi}

Konsepsi demokrasi selalu diidentikkan dengan penempatan rakyat pada posisi yang sangat strategis dalam sistem ketatanegaraan, walaupun pada tataran implementasinya terjadi perbedaan antara negara yang satu dengan negara yang lain. Karena berbagai varian implementasi demokrasi tersebut, maka di dalam literatur kenegaraan dikenal beberapa istilah demokrasi yaitu demokrasi konstitusional, demokrasi parlementer, demokrasi terpimpin, demokrasi Pancasila, demokrasi rakyat, demokrasi soviet, demokrasi nasional, dan lain sebagainya. (Saragih, 2000) Semua konsep ini menurut (Budiardjo, 2007) memakai istilah demokrasi, yang menurut asal kata berarti "rakyat berkuasa" atau government or rule by the people (kata Yunani demos berarti rakyat, kratos/ kratein berarti kekuasaan/berkuasa). Hal ini berarti bahwa pada tingkat terakhir rakyat memberikan ketentuan dalam masalah-masalah pokok mengenai kehidupan mereka, termasuk dalam menilai kebijaksanaan negara yang turut menentukan kehidupan mereka tersebut (Deliar Noer, 1983).

Jika dilihat dari kacamata politik, menurut (Robert A. Dahl, 1985) dalam gagasan demokrasi terdapat 5 (lima) kriteria, yaitu:

a. Persamaan hak pilih dalam menentukan keputusan kolektif yang mengikat;

b. Partisipasi efektif, yaitu kesempatan yang sama bagi semua warga negara dalam proses pembuatan keputusan secara kolektif;

c. Pembeberan kebenaran, yaitu adanya peluang yang sama bagi setiap orang untuk memberikan penilaian terhadap jalannya proses politik dan pemerintahan secara logis;

d. Kontrol terakhir terhadap agenda, yaitu adanya keputusan eksklusif bagi masyarakat untuk menentukan agenda mana yang harus dan tidak harus diputuskan melalui proses pemerintahan, termasuk mendelegasikan kekuasaan itu pada orang lain atau lembaga yang mewakili masyarakat; dan

e. Pencakupan, yaitu terliputnya masyarakat mencakup semua orang dewasa dalam kaitannya dengan hukum.

Secara komprehensif kriteria demokrasi juga diajukan oleh Gwendolen M. Carter, John H. Herz dan Henry B. Mayo. Carter dan Herz, (Budiardjo, 1982) mengonseptualisasikan demokrasi sebagai pemerintahan yang dicirikan oleh dan dijalankannya melalui prinsip-prinsip:

a. Pembatasan terhadap tindakan pemerintah untuk memberikan perlindungan bagi individu dan kelompok dengan jalan menyusun pergantian pimpinan secara berkala, tertib dan damai, dan melalui alat-alat perwakilan rakyat yang efektif;

b. Adanya sikap toleransi terhadap pendapat yang berlawanan;

c. Persamaan di depan hukum yang diwujudkan dengan sikap tunduk 
Fauzi Iswari: Aplikasi Konsep Negara Hukum Dan Demokrasi Dalam Pembentukan...

kepada rule of law tanpa membedakan kedudukan politik;

d. Adanya pemilihan yang bebas dengan disertai adanya model perwakilan yang efektif;

e. Diberinya kebebasan partisipasi dan beroposisi bagi partai politik, organisasi kemasyarakatan, masyarakat dan perseorangan serta prasarana pendapat umum semacam pers dan media massa;

f. Adanya penghormatan terhadap hak rakyat untuk menyatakan pandangannya betapa pun tampak salah dan tidak populernya pandangan itu; dan

g. Dikembangkannya sikap menghargai hak-hak minoritas dan perorangan dengan lebih mengutamakan penggunaan cara-cara persuasif dan diskusi daripada koersif dan represif.

Selanjutnya Henry B. Mayo (Budiardjo, 2007) menyatakan bahwa nilai-nilai yang harus dipenuhi untuk kriteria demokrasi adalah:

a. Menyelesaikan pertikaian-pertikaian secara damai dan sukarela;

b. Menjamin terjadinya perubahan secara damai dalam suatu masyarakat yang selalu berubah;

c. Pergantian penguasa dengan teratur;

d. Penggunaan pemaksaan seminimal mungkin;

e. Pengakuan dan penghormatan terhadap nilai-nilai keanekaragaman;

f. Menegakkan keadilan;

g. Memajukan ilmu pengetahuan; dan

h. Pengakuan dan penghormatan terhadap kebebasan.
Menurut pandangan lain, menurut (Afan Gaffar, 2005), demokrasi sebagai suatu gagasan politik merupakan paham yang universal sehingga di dalamnya terkandung beberapa elemen sebagai berikut:

a. Penyelenggara kekuasaan berasal dari rakyat;

b. Setiap pemegang jabatan yang dipilih oleh rakyat harus dapat mempertanggungjawabkan

kebijaksanaan yang hendak dan telah ditempuhnya;

c. Diwujudkan secara langsung maupun tidak langsung;

d. Rotasi kekuasaan dari seseorang atau kelompok ke orang atau kelompok yang lainnya, dalam demokrasi peluang akan terjadinya rotasi kekuasaan harus ada, dan dilakukan secara teratur dan damai;

e. Adanya proses pemilu, dalam negara demokratis pemilu dilakukan secara teratur dalam menjamin hak politik rakyat untuk memilih dan dipilih; dan

f. Adanya kebebasan sebagai HAM, menikmati hak-hak dasar, dalam demokrasi setiap warga masyarakat dapat menikmati hak-hak dasarnya secara bebas, seperti hak untuk menyatakan pendapat, berkumpul dan berserikat dan lain-lain.

Untuk mengimplementasikan semua kriteria, prinsip, nilai, dan elemen-elemen demokrasi tersebut di atas, Menurut (Saragih, 2000), perlu disediakan beberapa lembaga sebagai berikut:

a. Pemerintahan yang bertanggung jawab; 
b. Suatu dewan perwakilan rakyat yang mewakili golongan-golongan dan kepentingan-kepentingan dalam masyarakat yang dipilih dengan pemilihan umum yang bebas dan rahasia dan atas dasar sekurangkurangnya dua calon untuk setiap kursi. Dewan/perwakilan ini mengadakan pengawasan (kontrol) memungkinkan oposisi yang konstruktif dan memungkinkan penilaian terhadap kebijakan pemerintah secara kontiniu;

c. Suatu organisasi politik yang mencakup satu atau lebih partai politik. Partai-partai menyelenggarakan hubungan yang kontinyu antara masyarakat umum dan pemimpin-pemimpinnya;

d. Pers dan media massa yang bebas untuk menyatakan pendapat; dan

e. Sistem peradilan yang bebas untuk menjamin hak-hak asasi dan mempertahankan keadilan.

Berdasarkan uraian di atas, dapat dipahami bahwa cara yang paling aman untuk mempertahankan, kontrol atas Negara dalam arti negara hukum adalah melalui demokrasi. Hal ini karena ajaran yang menentukan bahwa sumber kekuasaan tertinggi atau kedaulatan dalam suatu Negara berada di tangan rakyat merupakan ajaran dari demokrasi itu sendiri. Dengan demikian, kehendak rakyatlah yang menjadi penentu segala aturan dan kekuasaan yang dijalankan oleh Negara.

Terkait dengan pembentukan undangundang, demokrasi dapat diwujudkan melalui partispasi rakyat atau partispasi publik. Hal ini bertujuan, agar undangundang yang akan dilahirkan sesuai dengan harapan masyarakat, karena dalam pembentukannya senantiasa memberikan ruang kepada masyarakat untuk ikut berpartisipasi. Partisipasi publik dalam pembentukan undang-undang tersebut dapat dilakukan secara langsung atau tidak langsung, dan juga secara individual maupun secara kolektif.

Dengan demikian, secara sederhana dapat dipahami bahwa dalam pembentukan undang-undang, demokrasi partisipatoris diharapkan lebih menjamin bagi terwujudnya produk undang-undang yang responsif, hal ini karena masyarakat diikutsertakan dalam membuat dan membidani lahirnya suatu undangundang.

\section{B. Aplikasi Konsep Negara Hukum dan Demokrasi dalam Pembentukan Undang-Undang di Indonesia}

Indonesia adalah salah satu negara yang terlahir pada abad modern melalui proklamasi 17 Agustus 1945, secara konstitusional "mengklaim" dirinya sebagai Negara hukum. Hal ini terindikasikan dengan adanya suatu ciri negara hukum yang prinsip-prinsipnya dapat dilihat pada Konstitusi Negara Republik Indonesia (sebelum dilakukan perubahan), yaitu dalam Pembukaan UUD NRI 1945, Batang Tubuh (non Pasal-pasal tentang HAM), dan Penjelasan UUD NRI 1945 dengan rincian sebagai berikut: 
Fauzi Iswari: Aplikasi Konsep Negara Hukum Dan Demokrasi Dalam Pembentukan...

1. Pembukaan UUD NRI 1945, memuat dalam alinea pertama kata "perikeadilan", dalam alinea kedua "adil", serta dalam alinea keempat terdapat perkataan "keadilan sosial", dan "kemanusiaan yang adil". Semua istilah itu berindikasi kepada pengertian negara hukum, karena bukankah suatu tujuan hukum itu untuk mencapai negara keadilan. Kemudian dalam Pembukaan UUD NRI 1945 pada alinea keempat juga ditegaskan "maka disusunlah kemerdekaan kebangsaan Indonesia itu dalam suatu Undang-undang Dasar Negara Indonesia".

2. Batang Tubuh UUD NRI 1945, menyatakan bahwa "Presiden Republik Indonesia memegang kekuasaan pemerintahan menurut Undang-undang Dasar (Pasal 14). Ketentuan ini menunjukkan bahwa presiden dalam menjalankan tugasnya harus mengikuti ketentuanketentuan yang sudah ditetapkan dalam Undang-undang Dasar. Pasal 9 mengenai sumpah Presiden dan Wakil Presiden "memegang teguh Undang-Undang Dasar dan menjalankan segala undang-undang dan peraturannya selurus-lurusnya". Melarang Presiden dan Wakil Presiden menyimpang dari peraturan perundang-undangan yang berlaku dalam menjalankan tugasnya suatu sumpah yang harus dihormati oleh Presiden dan Wakil Presiden dalam mempertahankan asas negara hukum. Ketentuan ini dipertegas lagi oleh Pasal 27 UUD NRI 1945 yang menetapkan bahwa "segala warga negara bersamaan kedudukannya dalam hukum dan pemerintahan itu dengan tidak ada kecualinya". Pasal ini selain menjamin prinsip equality before the law, suatu hak demokrasi yang fundamental, juga menegaskan kewajiban warga negara untuk menjunjung tinggi hukum suatu prasyarat langgengnya negara hukum; dan

3. Penjelasan UUD NRI 1945, merupakan penjelasan autentik dan menurut Hukum Tata Negara Indonesia, Penjelasan UUD NRI 1945 itu mempunyai nilai yuridis, dengan huruf besar menyatakan: "Negara Indonesia berdasarkan atas hukum (rechtsstaat) tidak berdasarkan atas kekuasaan belaka (machtsstaat)". Ketentuan yang terakhir ini menjelaskan apa yang tersirat dan tersurat telah dinyatakan dalam Batang Tubuh UUD NRI 1945. (Thaib, 2000)

Dari ketiga ketentuan di atas, penegasan secara eksplisit Indonesia sebagai negara hukum dapat dijumpai dalam Penjelasan UUD NRI 1945. Lain halnya dengan dua konstitusi (Konstitusi RIS dan UUDS 1950) yang pernah berlaku di Indonesia, terdapat penegasan secara eksplisit rumusan Indonesia sebagai negara hukum. Dalam Mukaddimah Konstitusi RIS misalnya disebutkan pada alinea ke-4: "untuk mewujudkan kebahagiaan, kesejahteraan, perdamaian, dan kemerdekaan dalam masyarakat dan Negara hukum Indonesia merdeka yang berdaulat sempurna." 
Kemudian di dalam Pasal 1 ayat (1) Konstitusi RIS juga disebutkan: "Republik Indonesia Serikat yang merdeka dan berdaulat ialah suatu Negara hukum yang demokrasi dan berbentuk federasi."

Demikian pula halnya, di dalam Mukaddimah UUDS 1950 pada alinea keempat menyebutkan:

"Maka demi ini kami menyusun kemerdekaan kami itu dalam suatu Piagam Negara yang berbentuk Republik Kesatuan, berdasar pengakuan Ketuhanan Yang Maha Esa, Perikemanusiaan, Kebangsaan, Kerakyatan dan Keadilan Sosial untuk mewujudkan kebahagiaan, kesejahteraan, perdamaian, dan kemerdekaan dalam masyarakat dan negara hukum Indonesia Merdeka yang berdaulat sempurna".

Kemudian di dalam Pasal 1 ayat (1) UUDS 1950 disebutkan: "Republik Indonesia yang merdeka dan berdaulat ialah negara hukum yang demokratis dan berbentuk kesatuan".

Setelah UUD NRI 1945 dilakukan perubahan/amandemen, rumusan negara hukum Indonesia yang semula hanya dimuat secara implisit baik di dalam Pembukaan maupun Batang Tubuh dan secara eksplisit dimuat di dalam Penjelasan UUD NRI 1945 sebelum perubahan. Penempatan rumusan negara hukum Indonesia telah bergeser kedalam Batang Tubuh UUD NRI 1945 yang secara tegas dinyatakan di dalam Pasal 1 ayat (3) UUD NRI 1945 yang berbunyi: "Negara Indonesia adalah Negara Hukum." Jika dikaitkan dengan unsurunsur negara hukum sebagaimana uraian pada pembahasan di atas, maka dapat ditemukan pengaturan unsur-unsur negara hukum dalam Batang Tubuh UUD NRI 1945 sebagai berikut:

1. Perlindungan terhadap hak-hak asasi manusia (HAM);

2. Pemisahan/pembagian kekuasaan;

3. Pemerintahan berdasarkan undang-undang; dan

4. Peradilan administrasi yang berdiri sendiri.

Dengan demikian, dalam sistem konstitusi Negara Indonesia cita negara hukum itu menjadi bagian yang tidak terpisahkan dari perkembangan gagasan kenegaraan Indonesia sejak kemerdekaan. Meskipun dalam pasal-pasal UUD NRI 1945 sebelum perubahan, ide Negara hukum itu tidak dirumuskan secara eksplisit, tetapi dalam penjelasannya ditegaskan bahwa Indonesia menganut ide "rechtsstaat", bukan "machtsstaat". Sementara dalam Konstitusi RIS tahun 1949, ide Negara hukum itu bahkan tegas dicantumkan, demikian pula dalam UUDS 1950, kembali rumusan bahwa Indonesia adalah negara hukum dicantumkan dengan tegas. Bahkan dalam Perubahan Ketiga pada tahun 2001 terhadap UUD NRI 1945, ketentuan mengenai negara hukum ini kembali dicantumkan secara tegas dalam Pasal 1 ayat (3) yang berbunyi: "Negara Indonesia adalah Negara Hukum”.

Merujuk pada uraian di atas, secara historis dan dalam konteks normatif sistem ketatanegaraan Indonesia dari awal kemerdekaan melalui UUD NRI 1945, Konstitusi RIS 1949, UUDS 1950, dan 
Fauzi Iswari: Aplikasi Konsep Negara Hukum Dan Demokrasi Dalam Pembentukan...

UUD NRI 1945 pasca amandemen dalam pengaplikasian konsep negara hukum selalu diselaraskan dengan nilai-nilai demokratis.

Dalam Pasal 28 UUD NRI Tahun 1945 misalnya, di sana ditegaskan bahwa: "Kemerdekaan berserikat dan berkumpul, mengeluarkan pikiran dengan lisan, tulisan dan sebagainya ditetapkan dengan undang-undang." Dengan demikian, maka secara jelas bahwa konstitusi negara kita telah memberikan jaminan serta perlindungan bagi masyarakat dalam mengeluarkan pikiran, baik secara lisan maupun tulisan, tidak terkecuali untuk membentuk perundang-undangan. (Putera Astomo, 2014)

Hal yang lebih spesifik terkait jaminan terhadap masyarakat untuk berpartisipasi dalam pembentukan undang-undang juga diatur dalam Pasal 96 Undang-undang Nomor 12 Tahun 2011 tentang Pembentukan PerundangUndangan, yang berbunyi sebagai berikut:

(1) Masyarakat berhak memberikan masukan secara lisan dan/atau tertulis dalam Pembentukan Peraturan Perundang-undangan.

(2) Masukan secara lisan dan/atau tertulis sebagaimana dimaksud pada ayat (1) dapat dilakukan melalui: a. rapat dengar pendapat umum; b. kunjungan kerja; c. sosialisasi; dan/atau seminar, lokakarya, dan/atau diskusi.

(3) Masyarakat sebagaimana dimaksud pada ayat (1) adalah orang perseorangan atau kelompok orang yang mempunyai kepentingan atas substansi Rancangan Peraturan

Perundang-undangan.

(4) Untuk memudahkan masyarakat dalam memberikan masukan secara lisan dan/atau tertulis sebagaimana dimaksud pada ayat (1), setiap Rancangan Peraturan Perundangundangan harus dapat diakses dengan mudah oleh masyarakat.

Jika kita telaah kembali terutama terkait pengaplikasian konsep negara hukum dan demokrasi dalam pembentukan undang-undang, dalam konteks kekinian maka kita akan berkesimpulan bahwa masih banyak undang-undang yang dibentuk oleh lembaga legislatif bersama lembaga eksekutif yang tidak sejalan dengan konsep negara hukum dan demokrasi. Hal ini karena masih adanya kecenderungan dari pembentuk undang-undang, mengabaikan prinsip atau asas negara hukum. misalnya (1) Asas Legalitas dan Prinsip kepastian hukum; (2) Aturan berdasarkan jenjang atau hierarki; dan (3) Perlindungan HAM.

Begitu juga dengan demokrasi, hal ini juga sering terlupakan dalam pembentukan undang-undang. Lembaga legislatif maupun eksekutif juga sering kali mengabaikan ketentuan yang ada dalam Pasal 96 Undang-undang Nomor 12 Tahun 2011 tentang Pembentukan Perundang-Undangan, terkait jaminan terhadap masyarakat untuk berpartisipasi dalam pembentukan undang-undang. Misalnya, masih saja kita menemukan ada undang-undang yang pembentukannya lebih didominasi oleh kebijakan yang 
bersifat politis dan menyampingkan penjaringan aspirasi publik. Kondisi yang demikian tidak jarang menimbulkan reaksi publik, sehingga undang-undang yang telah disahkan tersebut diminta oleh publik untuk mencabutnya. Upaya lain yang dilakukan oleh masyarakat terhadap undang-undang tersebut misalnya dengan mengajukan permohonan judicial review ke Mahkamah Konstitusi..

Idealnya, menurut M. Solly Lubis, sebagaimana dikutip oleh Putra Astomo, bahwa dalam perspektif demokrasi proses pembentukan hukum meniscayakan bahwa masukan-masukan (inputs) yang menjadi bahan pertimbangan untuk penentuan hukum itu bersumber dari masyarakat/rakyat dan juga merupakan aspirasi yang meliputi berbagai kepentingan hidup mereka. Aspirasi warga masyarakat tersebut disalurkan melalui wakil-wakil rakyat yang duduk di parlemen yang betul-betul jeli dan responsif terhadap kebutuhanmasyarakat masyarakat yang diwakilinya. Aspirasi masyarakat tersebut kemudian diproses di lembaga legislatif yang pada akhirnya akan melahirkan produk politik yang berupa hukum yang benar-benar mencerminkan aspirasi masyarakat. (Putera Astomo, 2014)

Kehadiran suatu undang-undang yang dibuat secara sepihak oleh pihak legislator akan sangat mungkin ditolak karena tidak sesuai dengan rasa keadilan dalam masyarakat. Di sinilah urgensi peran serta masyarakat dilibatkan dalam proses pembentukan undang-undang.
Dengan adanya partisipasi masyarakat dalam pembentukan undangundang secara tidak langsung akan menjadikan masyarakat lebih bermakna dan pemerintah lebih tanggap dalam proses demokrasi, sehingga pemerintahan yang dilahirkan adalah pemerintah yang bermoral, serta warga negara merasa bertanggung jawab dalam kehidupan bermasyarakat. (Samuel P. Huntington, 1994)

Sebagai salah satu keputusan yang bersifat publik, dihasilkan melalui pembentukan undang-undang. Hal ini karena undang-undang tersebut berisi halhal yang berkenaan dengan tatanan kehidupan bermasyarakat, berbangsa dan bernegara. Keputusan publik yang berupa undang-undang tersebut akan mengikat dan berlaku untuk seluruh rakyat dalam suatu negara. Maka dari itu, dalam proses pembentukan undang-undang tersebut harus memberikan ruang publik bagi masyarakat luas untuk bisa ikut berpartisipasi.(Saifudin, 2009)

Pada kenyataanya, di Indonesia saat ini sudah mulai mengarah pada pembangunan hukum yang secara tegas harus dikatakan telah mengarah pada posisi keluar dari konsep negara hukum dan demokrasi. Hal ini dipertegas dengan banyaknya undang-undang dan rancangan undang-undang yang mendapat penolakan dari masyarakat. Sebagai contoh konkrit penolakan publik terhadap undangundang, misalnya belum lama ini adanya tuntutan publik terhadap Undang-undang Ormas dan Undang-undang KPK yang 
Fauzi Iswari: Aplikasi Konsep Negara Hukum Dan Demokrasi Dalam Pembentukan...

dinilai cacat secara formil dan juga secara materiil.

Penolakan publik tidak hanya terhadap undang-undang saja, tetapi juga terhadap rancangan undang-undang. Sebut saja misalnya rancangan undangundang (RUU) Onmibus Law, RUU Haluan Ideologi Pancasila, RUU Pertanahan, RKUHP, dan sebagainya. Penolakan tersebut terjadi karena undangundang dan rancangan undang-undang tersebut mengabaikan prinsip-prinsip negara hukum dan demokrasi. Prinsip negara hukum misalnya menabrak Asas legalitas, prinsip kepastian hukum, dan perlindungan terhadap HAM. Sementara prinsip demokrasi yang diabaikan tentunya terkait dengan keterlibatan publik dalam pembentukan undangundang.

Penolakan publik terhadap undangundang dan rancangan undang-undang sebagaimana disinggung sebelumnya, sudah dapat dijadikan sebagai bukti bahwa baik lembaga legislatif maupun eksekutif dalam pembentukan undangundang tidak atau belum menerapkan konsep negara hukum dan demokrasi dengan baik. Akibat dari pembentukan undang-undang yang demikian akan mempengaruhi eksistensi Indonesia sebagai negara hukum serta akan menurunkan kualitas demokrasi yang dicanangkan oleh para founding fathers dan konstitusi.

\section{SIMPULAN}

Negara hukum itu harus ditopang dengan sistem demokrasi karena terdapat korelasi yang jelas antara negara hukum yang bertumpu pada konstitusi, dengan kedaulatan rakyat yang dijalankan melalui sistem demokrasi. Pengaplikasian prinsipprinsip negara hukum dan demokrasi dalam pembentukan undang-undang di Indonesia, idealnya tercermin dalam penerapan Asas legalitas, prinsip kepastian hukum, dan perlindungan terhadap HAM dalam sebuah undangundang. Sementara prinsip demokrasi dalam pembentukan undang-undang tampak dari adanya keterlibatan atau partispasi publik dalam pembentukan suatu undang-undang. Namun yang terjadi di Indonesia saat ini, dalam pembentukan undang-undang sudah mengarah pada pengabaian terhadap prinsip negara hukum dan demokrasi. Hal ini berdampak pada protes dan penolakan terhadap undang-undang yang sudah disahkan dan juga terhadap rancangan undang-undang yang sedang dibahas di lembaga legislatif.

\section{DAFTAR PUSTAKA}

A. Mukthie Fadjar. (2005). Tipe Negara Hukum (II). Malang: Bayumedia Publishing.

Afan Gaffar. (2005). Politik Indonesia; Transisi Menuju Demokrasi. Yogyakarta: Pustaka Pelajar.

Azhary, M. T. (2010). Negara Hukum Suatu Studi Tentang PrinsipPrinsipnya Dilihat dari Segi Hukum Islam, Implementasinya Pada Periode Negara Madinah Dan Masa Kini (IV). Jakarta: Kencana Prenada Media Group. 
Budiardjo, M. (1982). Masalah Kenegaraan. Jakarta: Gramedia.

Budiardjo, M. (2007). Dasar-dasar Ilmu Politik (XXX). Jakarta: Gramedia.

Cora Elly Noviati. (2013). Demokrasi dan Sistem Pemerintahan. Jurnal Konstitusi, 10(2), 334-335.

Deliar Noer. (1983). Pengantar ke Pemikiran Politik. Jakarta: CV. Rajawali.

Hadjon, P. M. (1987). Perlindungan Hukum Bagi Rakyat Di Indonesia Sebuah Studi tentang PrinsipPrinsipnya, Penanganannya Oleh Pengadilan Dalam Lingkungan Peradilan Umum dan Pembentukan Peradilan Administrasi Negara. Surabaya: PT Bina Ilmu.

HR, R. (2011). Hukum Administrasi Negara. Jakarta: PT RajaGrafindo Persada.

Jimly Asshiddiqie. (2010). Negara Hukum Indonesia. Jakarta.

MD, M. M. (1999). Hukum dan Pilarpilar Demokrasi. Yogyakarta: PT. Gama Media.

Muhammadong, N. (2017). Implementasi Prinsip Negara Hukum dan Demokrasi Dalam Pembentukan Peraturan Daerah. Jurnal HOLREV, 1(2), 169. Retrieved from http://ojs.uho.ac.id/index.php/holrev /

Putera Astomo. (2014). Pembentukan Undang-Undang dalam Rangka
Pembaharuan Hukum Nasional Di Era Demokrasi. Jurnal Konstitusi, 11(3), 591.

Robert A. Dahl. (1985). Dilema Demokrasi Pluralis: Antara Otonomi dan Kontrol. Jakarta: Rajawali Press.

Saifudin. (2009). Partisipasi Publik Dalam Pembentukan Peraturan Perundang-Undangan (1st ed.). Yogyakarta: UII Press.

Samuel P. Huntington. (1994). Partisipasi Politik di Negara Berkembang (2nd ed.). Jakarta: Rineka Cipta.

Saragih, M. K. dan B. R. (2000). Ilmu Negara (IV). Jakarta: Gaya Media Pratama.

Siallagan, H. (2016). Penerapan Prinsip Negara Hukum Di Indonesia. Sosiohumaniora, 18(2). https://doi.org/10.24198/sosiohuma niora.v18i2.9947

Soerjono Soekanto dan Sri Mamudji. (2007). Penelitian Hukum Normatif Suatu Tinjauan Umum. In Rajawali Pers, Jakarta (p. 23).

Surbakti, A. R. (1999). Demokrasi dan Hak-Hak Asasi Manusia. Jurnal Masyarakat Kebudayaan Dan Politik, XII(2), 3.

Thaib, D. (2000). Kedaulatan Rakyat, Negara Hukum dan Konstitusi (II). Yogyakarta: Liberty.

Wahjono, P. (1991). Membudayakan UUD 1945. Jakarta: IND HILL-Co. 